\title{
Akutt hjerteinfarkt og mitokondrielt DNA
}

\section{Mitokondrielt DNA kan detekteres i blodstrømmen etter hjerteinfarkt og kan utløse potensielt skadelig immunreaksjon i hjertet.}

Bedre akuttbehandling har ført til redusert dødelighet ved hjerteinfarkt, men $12 \%$ av dødsfallene i Norge skyldes fremdeles iskemisk hjertesykdom, og mange av pasientene som overlever, utvikler hjertesvikt. Tidlig reperfusjonsbehandling er viktig ved akutt hjerteinfarkt, men reperfusjon medfører skade på hjertemuskelcellene - blant annet gjennom inflammasjon. Mitokondrielt DNA er mitokondrienes eget arvestoff, har likheter med bakterielt DNA og kan være en utløsende faktor for den inflammatoriske reaksjonen etter akutt hjerteinfarkt.

I mitt doktorgradsarbeid deltok jeg i basalog translasjonsmedisinske studier hvor vi undersøkte hvorvidt mitokondrielt DNA kan detekteres i blodstrømmen til pasienter med hjerteinfarkt etter akutt hjertekateterisering og stenting, og hvorvidt mitokondrielt DNA kan utløse en potensielt skadelig immunreaksjon.

Vi viste for første gang at mitokondrielt DNA kan detekteres i blod hos pasienter med hjerteinfarkt og i en serie dyre- og celleeksperimenter at mitokondrielt DNA kan redusere mitokondrienes funksjon og føre til død av hjertemuskelceller. Videre fant vi at proteinet nukleolin som sitter i cellemembranen kan være ansvarlig for transport av mitokondrielt DNA inn i cellene.

Funnene indikerer at mitokondrielt DNA som lekker ut av hjertemuskelcellene ved akutt hjerteinfarkt, kan bidra til økt skade på hjertet.

\section{Lars Henrik Mariero}

mariero.lars@bcg.com

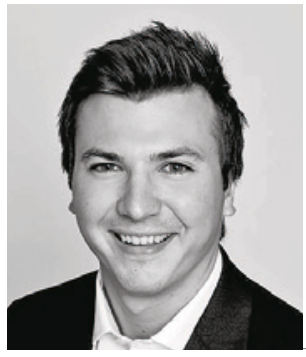

Lars Henrik Mariero. Foto: Fotograf Sjöwall

Disputas

Lars Henrik Mariero disputerte for ph.d.graden ved Universitetet i Oslo 29.10. 2015. Tittelen på avhandlingen er Mitochondrial DNA is a danger to the heart.

\section{Kliniske tegn og sykdomsmekanismer ved predemenstilstander}

\section{Skade på hvit substans i hjernen, synshallusinasjoner og depresjon kan være tidlige tegn på demenssykdom.}

Det forventes at antall demente i Norge, og verden, vil dobles de neste tiårene. Omkostningene knyttet til omsorg og pleie vil derfor $ø$ ke betraktelig. Det er gode holdepunkter for at det eksisterer en såkalt predemensfase som kan starte opptil flere tiår før pasientene utvikler demens. Det er et betydelig forskningssøkelys på debutsymptomer og påvisning av ulike biomarkører som kan avdekke underliggende sykdomsmekanismer i denne tidlige fasen.

I mitt doktorgradsarbeid inkluderte vi pasienter med mild Alzheimers sykdom og demens med Lewy-legemer, pasienter med nydiagnostisert Parkinsons sykdom uten demens og pasienter med subjektiv og mild kognitiv svikt. Sistnevnte er risikotilstander for en senere demensutvikling.

Hovedfunnene $i$ avhandlingen er at pasien- ter med demens med Lewy- legemer ofte debuterer med synshallusinasjoner og at depresjon kan være et tidlig symptom på demens som bringer pasientene i kontakt med lege. Vi fant også at forandringer i hvit substans i hjernene til pasienter med Parkinsons sykdom uten demens kunne påvises kort tid etter diagnosen, og at funnene korrelerte med reduserte prestasjoner på kognitive tester.

Hovedmålet med forskning på predemens er å forstå sykdomsmekanismer og på sikt kunne tilby behandling før irreversibel hjerneskade foreligger. Funnene gir oss viktig klinisk informasjon om mulige debutsymptomer ved demens og på hvilken måte demenssykdom starter i hjernen.

\section{Eirik Auning}

eirikauning@hotmail.com

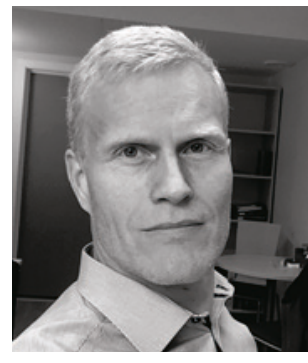

Eirik Auning. Foto: Privat

Disputas

Eirik Auning disputerte for ph.d.-graden ved Universitetet i Oslo 27.10. 2015. Tittelen på avhandlingen er Presenting symptoms, biomarkers and underlying brain changes in predementia Lewy body and Alzheimer's disease. 